\title{
PHYTOCHEMICAL SCREENING AND MINERAL COMPOSITION OF THE LEAVES OF OCIMUM GRATISSIMUM (SCENT LEAF)
}

\author{
Priscilla Alexander \\ Department of Chemistry, Adamawa State University, Mubi, Nigeria. \\ Email: priscillaalexander21@yahoo.com
}

\begin{abstract}
The leaves of Ocimum gratissimum having some ethno-medicinal applications were investigated. The phytochemicals screening of the leaves using Standard Methods and further analysis with HPLC revealed the presence of tannins, saponins, flavonoids, alkaloids, phlobatanins, terpenoids, steroids and cardiac glycosides. The elemental analysis was carried out using Atomic Absorption Spectrophotometer (AAS). The result revealed the presence of $\mathrm{Na}(0.311 \pm 0.049), \mathrm{Ca}(0.138 \pm 0.111), \mathrm{Mg}(1.712 \pm 0.537), \mathrm{K}(0.261 \pm 0.077), \mathrm{Mn}(0.457 \pm 0.107, \mathrm{~Pb}(0.005 \pm$ $0.002), \mathrm{Zn}(0.200 \pm 0.06), \mathrm{Cu}(0.803 \pm 0.818), \mathrm{N}(0.286 \pm 0.052)$, and $\mathrm{Fe}(0.312 \pm 0.067)$. Cd and Cr were not detected in the samples. This investigation suggested that Ocimum gratissimum leaves are rich in phytochemical constituents which contributed to its medicinal uses. The leaves of Ocimum gratissimum can be said to contain some components of medical value since the chemical components elaborated by it are active principles (alkaloid, steroids and glycosides). Ocimum gratissimum also contain most of the essentials elements indicating its nutritive values and less toxic as $\mathrm{Cd}$ and $\mathrm{Cr}$ were not detected in the leaf.
\end{abstract}

Keywords: Ocimum gratissimum; Phytochemical screening; elemental analysis.

\section{Introduction}

Plants are richest resources of drugs in the traditional and modern systems of medicine, nutraceuticals, food supplements, pharmaceutical intermediates and chemical entities for synthetic drugs (Hammer et al., 1999). The use of plants and plants products as medicines could be traced back to the beginning of human civilization. Medicinal plants are of great importance to the health of individual and the communities. The medicinal values of some plants lie in some chemical substances that produce definite physiological actions in the human body. The most important of these bioactive constituents are alkaloids, tannis, flavonoids and phenolic compounds. Many of these indigenous medicinal plants are used as spices and food plants (Okwu, 1999 \& 2001). An Ethno botanical and ubiquitous plant serves as rich resources of natural drugs for research and development (Kong et al, 2008).

Medicinal plants based drugs owe the advantage of being simple, effective and exhibit broad spectrum activity. The revival of interest in the use and importance of African medical plants by WHO and many developing countries has led to intensified efforts on the documentation of ethnomedical data of medicinal efforts. This is because most traditional healers keep no records and their information is passed on mainly verbally from generation to generation. Researchers are increasingly turning their attention to natural products looking for new leads to develop better drugs against cancer, as well as viral and microbial infections. The phytochemical evaluation of Ocimum gratissimum shows that it is rich in alkaloid, tannins, phytates, flavonoids and Oligosaccharides (Ijeh, et al., 2004). In the coastal area of Nigeria, the plant Ocimum gratissimum is used in the treatment of epilepsy, high fever and diarrhea (Sofowora, 1993; Ladipo et al., 2010).

The plant Ocimum gratissimum is one of those plants widely known and used for both medicinal and nutritional purposes. It is a perennial plant that is widely distributed in the tropics of Africa and Asia. It belongs to the Family Labiatae and it is the most abundant of the genus Ocimum. The common names of the plant are Basil Fever plant or Tea bush and vernacular names include Daidoya tagida (Hausa), Nichonwu (Igbo), Tanmotswangiwawagi (Nupe) and Efinrin (Yoruba) (Abdullahi et al., 2003; Idris et al., 2011).

It is woody at the base and has an average height of 1-3 meters. The leaves are broad and narrowly ovate, usually 5$13 \mathrm{~cm}$ long and $3-9 \mathrm{~cm}$ wide. It is a scented shrub with limegreen leaves (USDA, 2008). The plant is consumed by the Igbos as a leafy vegetables and the nutritional importance of this plant center on its usefulness as a seasoning because of its aromatic flavor. It is also used by the Igbos in the management of the baby's cord. It is believed to keep the baby's cord and wound surface sterile. It is used in the 
treatment of fungal infections, fever, cold and catarrh. Ocimum gratissimum is used through West Africa as antimalarial and anti-convulsant. The crushed leaf juice is used in the treatment of conlvusion, stomach pain and catarrh. Oil from the leaves have been found to possess antiseptics, antibacterial and antifungal activities (Edeoga and Eriata, 2001; Sofowara 1984).

The findings of Silva, et al (2005) show that the extracts of Ocimum gratissimum are active in vitro against human pathogenic dermatophytes. The aim of this present work therefore is to carry out phytochemical screening and elemental analysis of the sample.

\section{Materials and Methods}

\section{Sample Collection}

The plant leaves of Ocimum gratissimum (scent leaf) was collected from a farm at Mubi in Mubi South local government area of Adamawa State, Nigeria. The plant was identified in the Department of Biological sciences, Adamawa State University, Mubi, Nigeria. The residual moisture was evaporated at room temperature thereafter the fresh leaves samples were allowed to dry completely for two weeks at a room temperature before using them for this study.

\section{Sample Preparations and Extraction}

The air-dried plant sample was ground using pestle and mortar into a powdered form, sieved through $2 \mathrm{~mm}$ mesh sieve and stored in plastic container. The powdered sample was used for both phytochemical and elemental analysis.

An aliquot of $100 \mathrm{~g}$ of the plant sample was added into a $100 \mathrm{ml}$ of distilled water and $70 \% \mathrm{w} / \mathrm{v}$ ethanol, this gives the water and ethanol extract of $100 \mathrm{mg} / \mathrm{ml}$, the crude extraction was done at a room temperature. $100 \mathrm{~g}$ of the ground sample was soaked in $1000 \mathrm{ml}$ of distilled water and ethanol for 24hours at room temperature in order to obtain water and ethanol extract. Muslin cloth was used to filter the plant leaves residues and the filtrate obtained was further purified by filtration through Whattman No 1 filter paper under aseptic condition. The filtrate collected was then concentrated by using rotary evaporator. The extract was then collected in fresh sterile universal bottles and stored in the refrigerator at $4^{\circ} \mathrm{C}$ until when required for use (Atata $e t$ al 2003; Ladipo et al., 2010).

\section{Sample Preparation for Elemental Analysis}

$5 \mathrm{~g}$ of the dried powered sample was weighed into a crucible and gently heated over a hot plate until it is charred. The charred sample with the crucible was transferred into a muffle furnace and the temperature of the furnace was raised to about $550^{\circ} \mathrm{C}$, the sample was allowed to stay in the furnace until grayish white ash was obtained. It was allowed to cool at room temperature and then transferred inside desiccators. $5 \mathrm{~cm}^{3}$ of Conc. $\mathrm{HCl} / \mathrm{HNO}_{3}$ in the ratio of $1: 3$ was added into the ash and heated on a hot plate for 5minutes inside a fume cupboard until it reduces to $2 \mathrm{~cm}^{3}$. The mixture was allowed to cool, then transferred into a beaker and the crucible was washed several times with distilled water. The mixture was filtered into a $100 \mathrm{~cm}^{3}$ volumetric flask using No. 540 whatman filter paper and made up to the mark (AOAC, 2000).

\section{Phytochemical Analysis}

Phytochemcial screening was carried out using standard procedures to identify the constituents as describe by Sofowara (1993); Okwu, (2005) and Ladipo, (2010).

\section{Qualitative Analysis of the Constituents}

\section{Test for Tannins}

$0.5 \mathrm{~g}$ of the dried powdered sample was boiled in $20 \mathrm{~cm}^{3}$ of water in a test tube and was filtered. A few drops of $0.1 \%$ ferric chloride was added for observation of brownish green or a blue black colouration.

\section{Test for Phlobatanin}

Aqueous extract of the plant sample was boiled with $1 \%$ aqueous hydrochloric acid and deposition of a red precipitate was seen as an evidence for the presence of phlobatanins.

\section{Test for Saponins}

$2 \mathrm{~g}$ of the powdered sample was boiled in $20 \mathrm{~cm}^{3}$ of distilled water in a water bath and filtered. $10 \mathrm{~cm}^{3}$ of the filtrate was mixed with $5 \mathrm{~cm}^{3}$ of distilled water and was shaken vigorously for a stable persistent froth to be formed. The frothing was mixed with 3 drops of olive oil, and was shaken vigorously and then observed for the formation of emulsion.

\section{Test for Flavonoids}

$5 \mathrm{~cm}^{3}$ of $10 \%$ diluted ammonia solution was added to a portion of the aqueous filtrate of the plant extract, and then followed by addition of concentrated $\mathrm{H}_{2} \mathrm{SO}_{4}$. The observation of a yellow colouration in the extract indicated the presence of flavonoids.

\section{Test for Cardiac Glycosides}

$5 \mathrm{~cm}^{3}$ of the extract was treated with $2 \mathrm{~cm}^{3}$ of glacial acetic acid containing 1 drop of ferric chloride solution $(0.1 \%)$ was underlayed with $1 \mathrm{~cm}^{3}$ of concentrated $\mathrm{H}_{2} \mathrm{SO}_{4}$. A brown ring of the interface was indicated by a deoxysugar characteristic of cardenolides. The violet ring did not appear below the brown ring, while in the acetic layer, a greenish ring was not formed throughout thin layer.

\section{Test for Terpenoids}

$5 \mathrm{~cm}^{3}$ of the extract was mixed in $2 \mathrm{~cm}^{3}$ chloroform and $3 \mathrm{~cm}^{3}$ conc. $\mathrm{H}_{2} \mathrm{SO}_{4}$ was added, to form a layer. A reddish brown colouration of the interface was formed to show the positive result for the presence of terpenoids.

Test for Steroids

$2 \mathrm{~cm}^{3}$ of acetic anhydride was added to $0.5 \mathrm{~g}$ ethanolic extract of the sample with $2 \mathrm{~cm}^{3}$ of $\mathrm{H}_{2} \mathrm{SO}_{4}$. The colour does 
not change from violet to green to indicate the presence of steroids.

\section{Sample preparation for $(\mathrm{HPLC})$}

$5 \mathrm{~g}$ of prepared sample was placed into a $25 \mathrm{~cm}^{3}$ standard volumetric flask and make up to mark with buffer diluents. The solution was reflux, shaked, centrifuged and decanted. The filtrate was filtered using the HPLC grade filter paper.

\section{Results and Discussion}

The result of phytochemical screening Table 1 of Ocimum gratissimum showed that the plant leaves contains tannins, flavonoids, terpenoids alkaloids plobatannins, tannins saponins, steroids and glycosides. Further analysis of the phytochemicals constituents with HPLC ascertains that Ocimum gratissimum contains all the necessary phytochemical constituents. These metabolites are known to have varied pharmacological actions in man and animals, the presence of these metabolites suggest great potentials of the plants as a source of useful phytomedicines. The phytochemicals are naturally occurring chemicals in plants which serve as medicinal for the protection of human disease; the phytochemical are non nutritive plants chemical that have protection or disease preventive properties (Cheng et al., 2002).

Table 1: Phytochemical constituents

\begin{tabular}{|l|l|l|}
\hline Constituents & Result & HPLC \\
\hline Tannins & + & + \\
\hline Saponins & + & + \\
\hline Flavonoids & + & + \\
\hline Terpenoids & + & + \\
\hline Alkaloids & + & + \\
\hline Steroid & + & + \\
\hline Glycosides & + & + \\
\hline Plobatannis & + & + \\
\hline \multicolumn{2}{|c|}{$=$ Absent, $+=$ present } & \\
\hline
\end{tabular}

Alkaloids are also considered as nitrogenous bases that occur in plants, many of them have marked physiological effects on humans. Some alkaloids used as medicine are morphine, caffeine and coffee; in which caffeine in tea and coffee is alkaloids that stimulate the nervous system (Stanley et al., 2007). The presence of alkaloids suggests that it has potential antimicrobial activity on microorganisms. Some plants that posse alkaloids are known for decreasing blood pressure and balancing the nervous system in case of mental illness. Alkaloids are known to posses' anti-malaria property; hence the plants may be a good source of anti-malaria for which it is traditionally used (Stanley et al., 2007).

Flavonoids are polyphenolic compound that contribute to many other colours found in nature particularly the yellow and orange of petal, they have been reported to have antiviral and antiallegic activities. Presence of flavonoids might be responsible for its use as anti-inflammatory effects on both acute and chronic inflammation (Boham and Kocipai, 1994). The presence of saponins serves as potential activity of an antimicrobial agent. The presence serves as an indicator towards possible antibacterial activity. Saponins are a class of natural products involves and can be used to enhance penetration of micro molecules such as protein through cell membrane.

\section{Mineral content}

The result of the mineral composition of the leaves was presented in Table 2. The result revealed the presence of the essential elements such as $\mathrm{Mg}, \mathrm{K}, \mathrm{Cu}, \mathrm{Zn}, \mathrm{N}, \mathrm{Fe}, \mathrm{Na}$ and $\mathrm{Ca}$; which indicates the medicinal values of the plant. Different combination of these elements in the medicinal plant helps to cure the aliments. From the results of the investigation carried out, magnesium was the most abundant elements with the concentration of $1.712 \pm 0.537 \mathrm{mg} / \mathrm{kg}$. Magnesium helps in maintaining a normal heart rhythm and is sometimes given intravenously to reduce the chance of atrial fibrillation and cardiac arrhythmia (Holleman et al., 1988).

Table 2: Mineral composition $(\mathrm{Mg} / \mathrm{Kg})$.

\begin{tabular}{|l|l|l|}
\hline Elements & Concentration & WHO $(\mathbf{m g} / \mathbf{k g})$ \\
\hline Magnesium & $1.71 \pm 0.537$ & $0.62-2.64$ \\
\hline Potassium & $0.26 \pm 0.077$ & $0.07-0.34$ \\
\hline Manganese & $0.46 \pm 0.107$ & $0.23-0.67$ \\
\hline Copper & $0.80 \pm 0.818$ & $0.75-0.89$ \\
\hline Lead & $0.005 \pm 0.002$ & $0.01-0.03$ \\
\hline Zinc & $0.20 \pm 0.06$ & $0.16-0.34$ \\
\hline Nitrogen & $0.29 \pm 0.052$ & $0.45-0.67$ \\
\hline Iron & $0.31 \pm 0.067$ & $0.00012-0.46$ \\
\hline Sodium & $0.31 \pm 0.049$ & $0.048-0.56$ \\
\hline Calcium & $0.14 \pm 0.111$ & $0.24-0.28$ \\
\hline Cadmium & ND & $0.00012-0.00016$ \\
\hline Chromium & ND & $0.0024-0.0036$ \\
\hline
\end{tabular}

$( \pm)$ mean and standard deviation of three determinations.

ND - Not Detected

WHO - World Health Organisation

The concentration of sodium in the plant is $0.311 \pm$ $0.04 \mathrm{mg} / \mathrm{kg}$. Sodium has an important role in maintaining the water balance within cells and in the function of both nerve impulse and muscles. The sodium also helps in maintenance of normal acid-base balance. An adult need about $3 \mathrm{~g}$ per day of sodium but modern diatery habits take in 5-20 per day (Milbury et al., 2008). The sodium content of the plant is within the recommended level by WHO, 1995 (70.048 $0.56 \mathrm{mg} / \mathrm{kg}$ ).

Calcium $(\mathrm{Ca})$ was present at the concentration $(0.138$ $\pm 0.111 \mathrm{mg} / \mathrm{kg}$ ), which plays an important role in building 
and maintaining strong bones and teeth, large part of human blood and extracellular fluids. Approximately 99 percent of the body's calcium is stored in the bones and teeth (Holleman et al., 1988). The studied plant of O. gratissimum is essential in building up the level of calcium in the body.

The concentration of iron in the studied plan leaf of $\mathrm{O}$. gratissimum is $90.312 \pm 0.067 \mathrm{mg} / \mathrm{kg}$ ). The presence of iron shows that the plant is essential for red blood cell production and oxygen transport in the body as supported by the work of (Bahl and Bahl, 2006).

Lead $(\mathrm{Pb})$ was present at a very low concentration of $(0.005$ $\pm 0.0016 \mathrm{mg} / \mathrm{kg}$ ). Lead occurs naturally in the environment. Everyone may be exposed to trace amounts of leads through air, soil, household dust, food, drinking water and various consumer products (Shivery and Sofora, 2009).

The presence of $\mathrm{Cu}, \mathrm{Mn}$, and $\mathrm{Zn}$ indicates that the plant is essential for: immune function, protein synthesis, blood clothing, Hormones, formation of hemoglobin and for secretion and potentiating insulin action, this has been also reported by (Bahl and Bahl, 2006), and their concentrations in the plant leaf range as $\mathrm{Cu}(0.80 \pm 0.818 \mathrm{mg} / \mathrm{kg}), \mathrm{Mn}(0.46$ $\pm 0.107 \mathrm{mg} / \mathrm{kg})$ and $\mathrm{Zn}(0.20 \pm 0.006 \mathrm{mg} / \mathrm{kg})$ respectively. Copper is an essential element in the human body and exist as an integral part of copper proteins cerulosmin, which is concern with the release of iron from the cells into the plasma and is involved in energy metabolism (Bahl and Bahl, 2006).

Chromium in trivalent state is an essential trace element that potentiates insulin action and thus influences carbohydrate, lipid and protein (Shivery and Sofora, 2009). Chromium was not detected in plant leaf of O. gratissimum.

Cadmium was also not detected in the sample, cadmium causes kidney and liver problem including heart, brain and eyes problem on longer time of its accumulation (WHO, 1995). Ocimium gratissimum leaf is safe for consumption since these toxic elements were noted detected.

\section{Conclusion}

The phytochemical and elemental component of the leaves of Ocimum gratissimum was analysed. The result indicated that the leaf of the plant contains some major bioactive compounds that can inhibit the growth of microorganism, thereby proving it as an effective potentials source of antibiotic. However, the result revealed that the plant leaf contains saponins, tannins and alkaloids which help to inhibits bacterial growth. The plant extract might also be a potential source for drugs formulation as the plant leaves are used traditionally for curring of many infectious diseases. This study also justified that this plant leaf has significant nutritive values which are essential nutrients. Thereby, the plant leaf is good for consumption.

\section{References}

Abdullahi M, Muhammed G and Abdulkadir NU (2003) Medicinal and Economic plants of Nupeland, 1st edition, Jube Evans publisher, Bida, Niger state, Nigeria: 139.

AOAC (2000) Official methods of Analysis, $18^{\text {th }}$ edition. Association of Offical Analytical Chemists, Washinton, DC: $598-590$.

Atata RF, Sani A and Ajewole SM (2003) Effects of Stem, Bark Extracts of Enantia Chloranta on some clinical isolates. 15(2): 84- 92

Bahl A and Bahl B (2006) Alkaloids, Advance Organic Chemistry $6^{\text {th }}$ edition. S. Cahard and company ltd New Delhi, India. 1194- 1249.

Boham, BA and Kocipai-Abyazan R (1994) Flavonoids and condensed Tannins from leaves of Hawallan vaccinium vaticultum and Vaccinum calycinium. Pacific Sci; 48: 458463.

Cheng $\mathrm{H}$ and Linn $\mathrm{T}$ (2003) Antiherbs simplex Virus of Terminalia Arjuana Linn. Antiviral 55 (3) 47-55.

Edeoga HO and Eriata DO (2001) Alkaloids, Tannins and contents of some Nigeria medicinal plants. Journal of Medicinal Aromatic Plants Science, 23: 21-25

Hammer KA, Carson CF and Riley TV (1999) Antimicrobial Activity of Essential oils and other plants Extracts J. Appl. Microbiol. $86 \quad$ (6):985. DOI: $10.1046 /$ j.13652672.1999.00780.x

Holleman G, Arnold F, Wiberg G and Egon WN (1988) "Natrium" Lehrbuch der Anorganischen Chemie (in German) (91 100 ed.) Walter de Gruyter. Pp 931 -943. ISBN 311007511-3.

Idris S, Iyaka YA, Ndamitso MM and Paiko YB (2011) Nutritional Composition of the Leaves and Stems of Ocimum gratissimum. Journal of Emerging Trends in Engineering and Applied Sciences (JETEAS) 2 (5): 801-805

Ijeh II, Njoku OU and Ekenza EC (2004) Medicinal Evaluation of Xylopia Aethiopica Aromatics sciences 26(1): 4-44.

Kong JM, Goh NK, Chia LS and Chia TF (2008) Recent Advances in Traditional Plants Drugs and Orchads. Acta Pharmacology sciences 24: 7-21.

Ladipo MK, Doherty VF and Kanife UC (2010) Phytochemical Screening and antibacterial Investigation of The Extract of Ocimum gratissimum (Scent Leaf) On Selected Enterobacteriaceae. PAT 2010; 6 (2):75 -84 ISSN: 07945213

Milbury G, Paul G, Richer H and Alice (2008)Understanding the Antioxidant contravery; Scrutinizing the fountain of Youth Greenwood publishing group p 99.

Okwu DE (1999) Flavouring Properties of spices on Cassava futu. African J. Roots and Tuber crops 3(2): 19-21.

Okwu DE (2001). Evaluation of the Chemical Composition of Indegeneous Spice and Flavouring agents. Global J. of Pure and Applied Sci. 7(3): 455-459. 
Okwu DE and Okwu ME (2005) Chemical Composition of Spondias Mombia Linn Plant Parts. Journal of Sustain Agricultural environment. 6: 140-147.

Shivery D and Sofora A (2009) Medical Plants and Traditional Medicine in Africa. Spectrum Book Ltd, Ibadan, Nigeria, $\mathrm{p}$ 289.

Sofowara EA (1984) Medicinal plant and traditional medicine in Africa. Spectrum Books Ltd, Ibadan, Nigeria: 55-56.

Sofowora A (1993) Recent Trends in Research into African Medicinal plants. J. Ethnopharmacology. 38: 209-214. DOI: $10.1016 / 0378-8741(93) 90017-Y$
Stanley D (2007) Anogeissus Leiocarpus (DC). Grill. And per. No 119.

USDA (2008) United States Department of Agriculture research. Agriculture research service, Beltsville, Germplasm Resources Information Network.

WHO (1995) Evaluation of certain food additives and contaminants. Joint FAO/WHO Expert Committee on Food Additives.WHO Technical Report 859:29-35.s 